\title{
Skin Features Score 2
}

National Cancer Institute

\section{Source}

National Cancer Institute. Skin Features Score 2. NCI Thesaurus. Code C131041.

Superficial sclerotic features; not hidebound (able to pinch). 